\title{
A conceptual learner discipline management model for secondary schools in Mauritius
}

\author{
Belle Louis Jinot ${ }^{1}$, Van Niekerk Eldridge Johannes ${ }^{2}$ \\ ${ }^{1}$ Academic Affairs Division, Open University of Mauritius, Reduit, Mauritius \\ ${ }^{2}$ Department of Educational Leadership and Management, University of South Africa, Pretoria, South Africa
}

\section{Article Info \\ Article history: \\ Received Apr 21, 2021 \\ Revised Aug 9, 2021 \\ Accepted Sep 14, 2021}

\section{Keywords:}

Conception of discipline

Management

Positive

Punitive

Reform

Secondary schools

\begin{abstract}
Learner discipline management is a major but challenging function of school leadership. Adolescents of the 21 st century are complex in nature, and school stakeholders are having much difficulty to handle the problem of indiscipline in secondary schools. This paper aims at providing a conceptual model framework for learner discipline management. This model is the result of an empirical investigation conducted in four secondary schools. Focus group discussion and individual interviews were carried out with 80 participants, including 24 teachers, 24 learners, 24 parents, four school principals, and four school superintendents. The non-participant observation was also conducted in the four schools. Based on the conceptual, theoretical and empirical literature on positive, proactive, preventive and restorative discipline, the researcher proposed the model that considers all the researchand evidence-based strategies that are combined with the current effective measures prescribed by the Ministry of Education, Science and Technology of Mauritius. The model is framed within the context of the Nine Year Continuous Basic Education reform that requires a shift in the conception of discipline from the punitive or reactive approach to the positive approach. This paper formulates a conceptual model framework to implement in an attempt to prevent, reverse and restore discipline among learners in secondary schools.
\end{abstract}

This is an open access article under the CC BY-SA license.

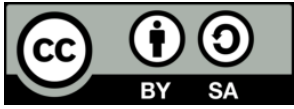

\section{Corresponding Author:}

Belle Louis Jinot

Academic Affairs Division

Open University of Mauritius

Reduit, Mauritius

Email: 1.belle@open.ac.mu

\section{INTRODUCTION}

Learner discipline is a multifaceted and complex phenomenon in educational institutions across the world; Mauritius is no exception. A lack of it is a public health problem [1]. It has always been a fundamental issue in schools, for all stakeholders, namely: the school principals, policymakers, police, parents, and teachers [2]. Manifestations of learner indiscipline in Mauritius include violence, bullying, stealing, drug trafficking, physical assaults, truancy acts, synthetic drug abuse, pornography on the mobile phone, lateness, use of abusive language, bunking classes. These manifestations are often committed both within and outside the premises of the school [3], [4]. The seriousness of the problem is reported in the 2007 and 2011 reports of the Global School-based Student Health Survey in which it is stated that an average of $34 \%$ of learners in Mauritius is physically aggressive in schools at least once every year [5].

From the custodial perspective, discipline is considered as punishment. It is defined as the degree of order and structure that helps the learner to manifest socially desirable behavior [6]. However, following the 
failure of the punitive or reactive approach to learner discipline management, there is a shift in its definition. Discipline is rather viewed from the humanistic, restorative, positive, preventive or proactive perspective, whereby discipline is not imposed but taught [7]-[11].

However, from an analysis of the official documents of the Ministry of Education, Tertiary Education, Science and Technology of Mauritius, Mauritius, the traditional approach to discipline is still being used. The school management manual for secondary school principals and the student behavior policy proposes the following discipline measures: verbal or written warning, detention, out-or-school suspension, special report, support from the school discipline and pastoral committee, and counselling from the educational psychologist [12], [13]. The protocol for school principals to address discipline problems is prescribed by the Ministry of Education, and it consists of all punitive measures. They are all strategies that the school head must adopt only when the lack of discipline is manifested. Despite the prescribed protocol from the Ministry of Education, Tertiary Education, Science and Technology, during the past decade, indiscipline among learners has been increasing in 'intensity and frequency' in Mauritian secondary schools [14]. It is noted that Mauritian learners of the 21st century are more recalcitrant and assertive [15]. No research has been done in the country on the possible positive discipline measures that can be adopted to prevent and address the problem of indiscipline among learners in secondary schools.

It should be noted that studies stressed that learner discipline should be perceived as positive guidance and self-discipline or the "internalization of discipline" [16], [17]. At the 2015, World Education Forum, a more humanistic approach to education and discipline was recommended [18]. Besides, it was recommended that education for 2030 should equip learners with skills that would make them more active, responsible and engaged citizens [19]. In the Mauritian context, schools should teach learners with values such as perseverance, integrity, patience and discipline [20]. In the context of the Nine Year Schooling Continuous Basic Education Reform, the government of Mauritius aims at inspiring adolescents to become self-motivated, independent lifelong learners, and responsible Mauritian citizens who are guided by human and societal values that ensure a safe society [21]. This reconceptualization of education and discipline necessitates a new approach to learner discipline [22].

Within this new context of educational reforms in Mauritius and the vision of the new Minister of Education, Tertiary Education, Science and Technology, this study aims to formulate a conceptual model that considers discipline management from the humanistic, egalitarian and democratic perspective. This is conceived from the waves of the school-wide positive behavior interventions and supports. Learner discipline management is considered as whole-school, holistic approach that put the learner at the center of the discipline strategies, whereby he/she is not considered as the problem, but rather part of the solution.

The research objectives of this study are: i) To discuss the various positive, proactive and preventive strategies that secondary schools may adopt to address the discipline problem among learners; and ii) To develop a learner discipline model that addresses the discipline problem in secondary schools from a wholeschool and holistic approach.

\section{RESEARCH METHOD}

This study aimed at conceptualizing a model that is contextualized for the Mauritian context. It is based on the researcher's investigation on the causes and strategies that school principals and teachers currently adopt to address learner indiscipline in Mauritian secondary schools, as well as the evidence-based behavioral preventions and interventions that have proved to be successful in another school context.

The qualitative research design was chosen for this study. The researchers used the deductive and exploratory approach to carry out the research inquiry. The research design offered him unique ways to collect data about people and social phenomena [23]. This helped to gain in-depth understanding of learners' behavior to discipline in the school setting. Their behavior is the result of their personal and social interactions with adults and among themselves. Researchers had to observe the learners', the educators', the school superintendent's and the principals' behavior in their daily real-life natural setting. For qualitative research, context matters [24].

The researchers use purposive sampling for this study. Researchers do not need to work with a sample that is a statistical representation of the population; rather they select people or cases 'with purpose' so that it may deeply explore the research questions [25], [26]. Purposive sampling is used mostly in studies in the field of leadership since it takes researchers to the type of individuals, they are looking for to participate in their studies [27].

Focus group discussions were conducted in four selected state secondary schools with 24 teachers, 24 parents of the Parents-Teachers Association, and 24 students of the student council; individual interviews with four school principals, and four school superintendents. Teachers had at least five years of professional experience in teaching; parents formed part of the School Governing Bodies; the learners formed part of the 
student council, should be aged between 11 and 18 years old; and the principals had at least five years of experience in the post of school principal. In addition to these 80 participants, non-participant observation was done for sixty hours by the researcher on the four selected secondary schools. The researchers of this study used a mixture of data collection techniques such as focus group interview, observation and individual interview. This helped them seek rich outputs and profound results; hence promoting trustworthiness by increasing validity based on triangulation [28], [29]. This data collection process was interactive as the three techniques involved the researchers and the different sets of participants such as teachers, learners, superintendents, parents and principals. The researchers used multi data collection instruments to ensure the validity of the findings. Indeed, information gathered from various sources ensures broader perspectives for analysis and representation [30]. Multiple instruments are used to collect data, corroborate them and confirm the information obtained to increase the credibility of the study [31].

Before data collection process, permission was obtained from the Ministry of Education, signed consent letters were obtained from the adult participants and assent letters were obtained from the vulnerable group (students), with the approval of their parents. The anonymity and confidentiality of the participants were ensured and their participation was purely voluntary. They were assured that no harm would be made.

Descriptive field notes were used to summarize what was seen and heard in the settings in much detail with verbatim conversations and direct quotes, and reflective field notes were used to describe the researcher-observer's feelings, thoughts and reactions about what they observed [32]. A log was kept for these purposes. Content analysis as well as thematic analysis were done to determine the emergent themes from the transcribed interviews and the observation log. The qualitative data analysis was processed as: getting familiar with the data, coding, generating themes, reviewing themes, defining and naming themes, and writing up the findings [33]. The Atlas.Ti software was used for the analysis purpose.

Debriefing and member checking were used after the final report on the findings. The purpose of the research was not the generalization of the findings due to its context-boundedness, but their transferability might be possible. The study allowed the readers to have sufficient information about the characteristics of the selected respondents and participants, and the natural setting of the study so that they may experience a congruence of their setting, features, and experiences with those found in this study. Ethics were considered in accordance to the Mauritius Data Protection Act (2017).

From the empirical investigation, it was found that the causes of learner indiscipline are the family, the learners' negative attitudes, the teachers' passive attitudes, the principal's lack of leadership and authority, peer group pressure, and the child's constitutional rights. Besides, the barriers to the effective implementation of the current discipline strategies adopted by principals in the country are the political interference of parents, the free transport system for learners to school, frustrated acting principals and deputy principals, too much bureaucracy when reporting a case of indiscipline to the Ministry, a lack of collaboration among the stakeholders, a lack of parental involvement, and a lack of government initiatives to restore discipline. The current discipline strategies that are adopted to address learner indiscipline in Mauritius are parental conferencing, visionary leadership, inclusive leadership, special report, video surveillance camera, corporal punishment, detention, suspension, and the e-register system and the attendance pink card to monitor learner attendance. These findings are used as a basis for the conceptual model, as presented in Figure 1.

\section{RESULTS AND DISCUSSION}

Learner discipline management must take a holistic approach requiring all the stakeholders of the school to successfully implement the model as a whole-school behavioral management approach. The model consists of primarily the universal prevention strategies that minimize the occurrence of indiscipline, the intervention strategies that reverse it, and the restorative strategies that restore positive discipline among learners.

\subsection{Learner discipline management model \\ 3.1.1. Universal discipline strategies}

Universal prevention strategies are taken to define, teach and monitor the behavior of all learners. They ensure that learners do not manifest indiscipline and minimize the number of learners who may require intervention [34]-[37]. The research-based universal prevention strategies that the school may adopt are parenting training, pre-correction, the teaching of social and prosocial skills, a differentiated curriculum and the teaching of rules and behavior expectations. When the universal prevention strategies are not effective in meeting all learners' needs and it is observed that some of them are manifesting indiscipline, then the intervention strategies, are adopted by the principal. 


\subsubsection{Intervention strategies}

Intervention strategies are adopted when learners are indiscipline on account of risk factors such as poor school attendance, poverty, low academic performance, peer group pressure, lack of family support, poor self-esteem, poor oral reading. These learners manifest many acts of aggression towards others on the school premises. Such strategies are opportunities to respond (OTR), choice-making, positive peer reporting, praise, behavior contract, compliance training, replacement behavior, active learner supervision, selfmanagement, effective instructional techniques, Check-in/Check-out (special report), Good Behavior Game, counselling referrals, and attendance records.

These strategies are not always sufficient: previous research has shown that at least $5 \%$ to $7 \%$ of the learners of a school may have emotional and behavioral disabilities that are linked to a lack of social and emotional capital and to family problems. Therefore, in addition, the model suggests restorative strategies which teach learners how to be accountable and responsible for "repairing the harm" they do to others and to reconnect to the victims in a positive manner [38].

\subsubsection{The restorative strategies}

The school adopt restorative strategies to make learners responsible for their indiscipline. They encourage mutual understanding of rules that learners should own [39], [40]. The restorative strategies are role-playing, teaching of conflict resolution skills, responsible contract, emotional resilience programmes, differentiated curriculum, restorative dispute resolution, problem-solving circles, and restorative circles and conferences.

\subsection{The learner discipline management implementation cycle}

The proposed model can only be implemented by following the learner discipline management cycle, designed by the researcher to facilitate its implementation process. It is an on-going process. The point of departure of the implementation process of the model is the identification of the learners with discipline problems. The identification is done by the School Disciplinary Team (SDT) and the process ends with an evaluation of the outcomes of the implementation by the team. The purpose of the review stage is to provide scope for improvements in the learner discipline management strategies to make it the most effective possible.

Once the principal does the purposing in terms of his/her vision for learner discipline in the school, he/she sets up the SDT in which there are two senior teachers of the School Management Team (SMT), two parents of the Parents-Teachers' Association (PTA), two members of the student council, two prefects from the higher forms, the social worker, the school-based educational psychologist, and the principal who leads the team.

The SDT together with the Form Masters and other teachers does a situational analysis of learner discipline in the school in an attempt to collect data at the beginning of the term. The discipline observation form, developed by the SDT, is used for data collection in terms of the names of the disruptive learner, the nature of the indiscipline, the circumstances of the occurrence, the harm caused to other learners or persons or any damage to property, and the names of the victim. The principal advocates the daily adoption and integration of the universal prevention strategies in the teaching and learning process, whatever the discipline status is in the school.

Based on the collected data, learner discipline is done in terms of behavior problem categorization: mild, moderate or severe. Then, the team may decide on the intervention strategies that the principal may adopt to restore learner discipline. In case of mild indiscipline, the SDT reminds the learner of the importance of socially acceptable learner behavior. At this stage, it is sufficient to do learner discipline management by talking. No need for behavior intervention strategies. Nevertheless, for modest and severe indiscipline, the SDT implements one or a mixture of the intervention strategies. When there is physical aggression of other learners, the SDT adopts the restorative strategies. It should be noted that the three categories of measures in the conceptual model are effective research- and evidence-based strategies. The principal with the SDT is responsible to monitor discipline after the intervention to examine any favorable progress or worsening of learner behavior. The evaluation process helps the SDT to determine the strengths and weaknesses of the implemented measures, and find alternative approaches within the model. 


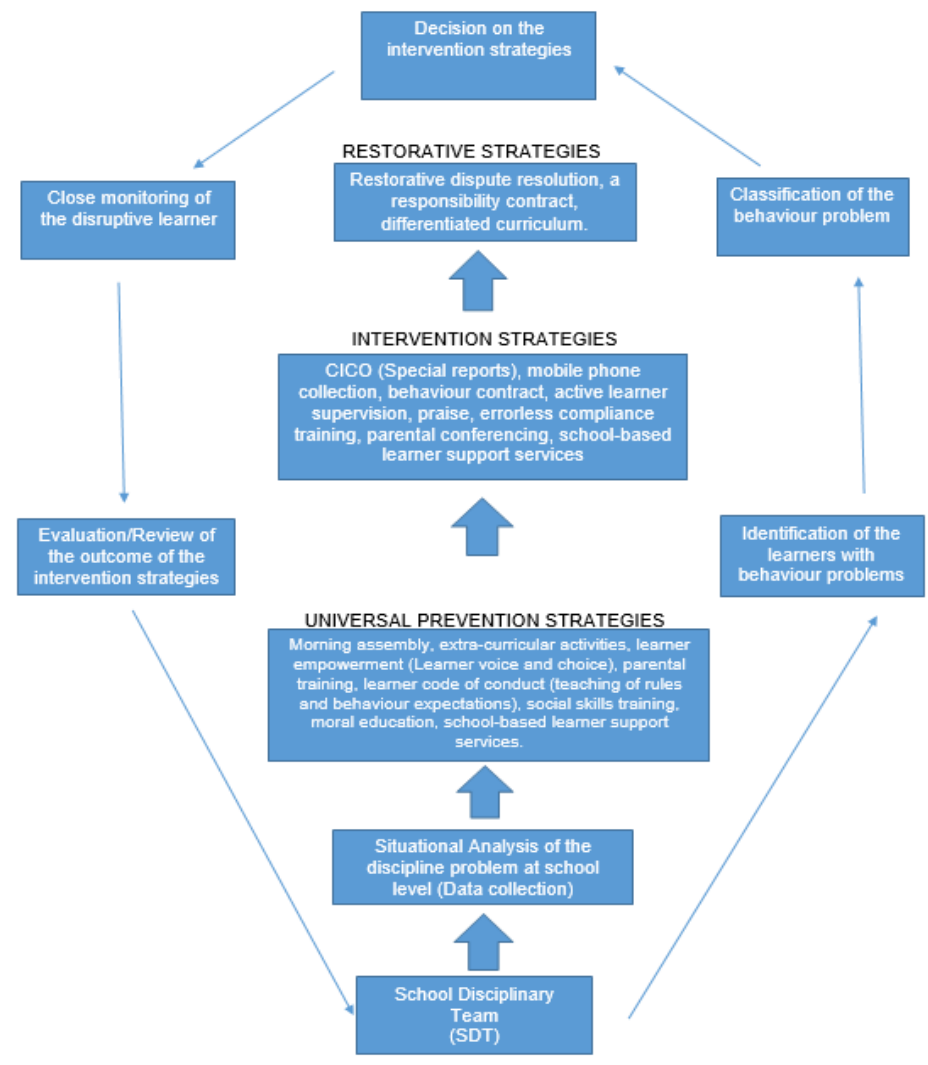

Figure 1. The conceptual model of learner discipline management

This model is unique to the context of secondary schools in Mauritius, as it is conceived from the positive and humanistic approaches to the discipline problem among students. From the existing discipline management policies and strategies proposed and imposed by the Ministry of Education, Tertiary Education, Science and Technology, the punitive and reactive approach is adopted. Verbal or written warning, detention, out-or-school suspension, special report, support from the school discipline and pastoral committee, and counselling from the educational psychologist [12], [13] are all punitive measures proposed in the Student Behavior Policy and the School Management Manual of the Ministry. This model is an alternative approach to the problem. It proposes evidence-based strategies [41] that have been proved to be effective in the developed world, by taking into consideration the context of the Mauritian education system.

Based on the conceptual model, it is recommended that the stakeholders of the education system, including the Ministry of Education, Tertiary Education, Science and Technology to reconceptualize the discipline problem by shifting the focus from the behavior modification approach to the democratic and egalitarian approach which put the learner at the center of the adoption of any behavior management strategy. Self-discipline is the major aspect of the discipline policy. So, social workers, educational psychologists, special needs teachers, general education teachers, health officers, parents, the school superintendents, and the school community must collaborate to implement the proposed model, so that a holistic approach can be adopted to address the discipline problem in each school.

The decentralization of the school management should replace the centralization, so that learner discipline management is contextualized and unique to each school. The strategies should neither be imposed by the Ministry nor generalized. This whole-school approach to learner discipline management is based on the decentralization models which view the school as a community of people having the school mission at heart and which advocate the school-based management [42].

\section{CONCLUSION}

The proposed learner discipline management model was designed based on the qualitative findings of previous research on learner discipline management in Mauritius. It is the well-grounded in the conceptual, theoretical and empirical literature, which falls outside the purpose of this paper. This paper formulates a conceptual model framework to implement in an attempt to prevent, reverse and restore 
discipline among learners in secondary schools. The value of the model is that it is based on an in-depth investigation within a context-bound setting that may be transferred to another setting with the same characteristics of the research setting. It is only a conceptual model that needs to be tested in order to assess the effectiveness of its implementation. This may be a subject for further research in the present context or in any other context.

\section{ACKNOWLEDGEMENTS}

Authors would like to thank the University of South Africa for the bursary that was awarded to conduct the research.

\section{REFERENCES}

[1] S. G. Mwaniki, "Students' indiscipline: A reflection on the causes of misbehavior among learners in Kenyan secondary schools," Global Journal of Advanced Research, vol. 5, no. 4, pp. 171-177, 2018.

[2] A. A. Ali, I. T. Dada, G. A. Isiaka, and S. A. Salmon, "Types, causes and management of indiscipline acts among secondary school students in Shomolu Local Government Area of Lagos State," Journal of Studies in Social Sciences, vol. 8, no. 2, pp. 254-287, 2014

[3] Mauritius Research Council (MRC), Discipline/Indiscipline and violence in secondary schools. Rose Hill: La Maison de Carne, 2006.

[4] R. Seegopaul, "An evaluation of the work of a school head as the manager to improve discipline in a school: A case study in a model school in Mauritius," Unpublished Dissertation, Open University of Mauritius, 2016.

[5] Ministry of Health and Quality of Life, Global School-based Student Health Survey 2011: Country Report. Republic of Mauritius, 2013.

[6] F. E. Ugboko and A. Adediwura, "A study of principal supervisory strategies and secondary school discipline," Journal of Educational and Social Research, vol. 2, no. 1, pp. 41-49, 2012.

[7] D. Smith, D. Fisher, and N. Frey, Better than carrots or sticks: Restorative practices for positive classroom management. ASCD Publishing, 2015.

[8] J. L. Weaver and J. M. Swank, "A case study of the implementation of restorative justice in a middle school," Research in Middle Level Education (RMLE), vol. 43, no. 4, pp.1-9, 2020, doi: 10.1080/19404476.2020.1733912.

[9] J. Dubin, "Learning to switch gears in New Haven: A restorative approach discipline," American Educator, vol. 39, no. 4, pp. 17-21, 2016.

[10] K. Otto, "The role of restorative discipline in the school system," BU Journal of Graduate Studies in Education, vol. 8, no. 1, pp. 46-49, 2016.

[11] L. Sikanda and M. Mpofu, "Positive discipline practices in schools: A case study of Mzilikazi District secondary schools in Zimbabwe," Journal of Education and Social Research, vol. 7, no. 3, pp 117-125, 2017.

[12] Ministry of Education, Culture and Human Resources, School management manual: Policies, procedures, and guidelines on school management issues. IVTB House, Phoenix: School Management Division, 2009.

[13] Ministry of Education and Human Resources, Tertiary Education and Scientific Resources, The Student Behaviour Policy. Phoenix: IVTB House, 2015.

[14] O. A. Opere, I. Kamere, and V. Wawire, "School violence as a course of non-peaceful coexistence in public secondary school in Nairobli, Kenya," Open Journal of Social Sciences, vol. 7, no. 9, pp. 130-145, 2019, doi: 10.4236/jss.2019.79010.

[15] P. Mishra and R. Mehta, "What we educators get wrong about 21st century learning: Results of a survey," Journal of Digital Learning in Teacher Education, vol. 33, no. 1, pp. 6-19, 2017, doi: 10.1080/21532974.2016.1242392.

[16] O. T. Obadire and D. A. Sinthumule, "Learner Discipline in the post-corporal punishment: What an experience!" South African Journal of Education, vol. 41, no. 2, pp. 1-9, 2021.

[17] F. Jones, Positive classroom discipline. New York: McGraw-Hill, 1987.

[18] UNESCO, World Education Forum 2015. Paris: UNESCO, 2015.

[19] Organisation for Economic Co-operation and Development (OECD), Innovative citizen, partnership project, 2018. [Online]. Available: https://www.oecd.org/gov/OECD-Innovative-Citizen-Participation-Project.pdf.

[20] R. Hidayah, E. Muawanah, A. Zamhari, M. Munardji, and N. Naqiyah, "Learning worship as a way to improve students' discipline, motivation and achievement at school," Journal of Ethics and Cultural Studies, vol. 8, no. 3, pp. 292-310, 2021.

[21] Ministry of Education and Human Resources, Tertiary Education and Scientific Research, La reforme educative: Le nine-year schooling. Phoenix: IVTB House, 2016.

[22] B. L. Jinot, "Learner Discipline Management in Secondary Schools in Mauritius: A Misconception," International Journal of Innovative Research and Advanced Studies, vol. 4, no. 12, pp. 20-23, 2017.

[23] L. M. Abbott and J. McKinney, Understanding and applying research design. New Jersey: John Wiley \& Sons, Inc, 2013.

[24] C. Marshall and G. B. Rossman, Designing qualitative research. London: Sage Publications, Inc, 2014.

[25] B. Matthews and L. Ross, Research methods: A practical guide for the social sciences. London: Pearson Education Ltd, 2010. 
[26] W. A. Edmonds and T. D. Kennedy, An applied reference guide to research designs: Quantitative, Qualitative and mixed methods. Thousand Oaks, CA: Sage, 2012.

[27] M. Brundrett and C. Rhodes, Researching educational leadership and management: Methods and approaches. Thousand Oaks, CA: Sage, 2014.

[28] J. Biggam, Succeeding with your master's dissertation: A step-by-step handbook. London: McGraw-Hill International Ltd, 2011.

[29] G. B. Rossman and S. F. Rallis, Learning in the field: An introduction to qualitative research. Massachusetts: SAGE Publications, Inc, 2012.

[30] J. Saldana, The coding manual for qualitative researchers. London: Sage, 2009.

[31] B. W. Tuckman and B. E. Harper, Conducting educational research. London: Rowan \& Littlefield Publishers, Inc, 2012.

[32] M. G. Lodico, D. T. Spaulding and K. H. Voegtle, Methods in educational research: From theory to practice. San Francisco, CA: Jossey-Bass, 2010.

[33] J. Caulfied, "How to do thematic analysis?" Scribbr, 2019. [Online]. Available: https://www.scribbr.com/methodology/thematic-analysis.

[34] G. Sugai and R. H. Horner, "What we know and need to know about preventing problem behaviour in schools," Exceptionality, vol. 16, no. 2, pp. 67-77, 2008.

[35] U.S Department of Education, Guiding principles: A resource guide for improving school climate and discipline. Washington D.C: U.S Department of Education, 2014.

[36] I. Darjan and M. Tomita, "Proactive strategies for efficient discipline policy," Journal of Community Positive Practices, vol. 14, no. 2, pp. 28-36, 2014.

[37] T. J. Lewis and G. Sugai, "Effective Behaviour Support: A systems approach to proactive schoolwide management," Focus on Exceptional Children, vol. 31, no. 6, pp. 1-14, 1999, doi: 10.17161/foec.v31i6.6767.

[38] R. Hendry, Building and restoring respectful relationships in schools: A guide to restorative practice. London: Routledge, 2009.

[39] G. McCluskey, "Restorative approaches in schools: current practices, future directions," in The Palgrave International Handbook of School Discipline and Social Control. Palgrave Macmillan, Cham, 2018.

[40] H. Lustick, "Making Discipline Relevant: Toward a Theory of Culturally Responsive Positive Schoolwide Discipline," Race, Ethnicity and Education, vol. 20, no. 5, pp. 681-695, 2016, doi: 10.1080/13613324.2016.1150828.

[41] M. Dadds and L. Tully, "What is it to discipline a child: What should it be? A reanalysis of Time-outfrom the perspective of child mental health, attachment, and trauma," American Psychologist, vol. 74, no. 7, pp. 794-808, 2021, doi: 10.1037/amp0000449.

[42] D. Allam, "Explaining the persistence of "decentralization" of education in Egypt," International Journal of Educational Development, vol. 82, 2021, doi: 10.1016/j.ijedudev.2021.102357. 